\title{
An Empirical Model: Jewish and Muslim Women Students in Israel Gaining Empowerment Through Higher Education
}

\author{
Anat Gilat \\ The School for Advanced Studies, Gordon College of Education, Haifa, Israel.
}

\begin{abstract}
How to cite this paper: Anat Gilat (2020). An Empirical Model: Jewish and Muslim Women Students in Israel Gaining Empowerment Through Higher Education. The Educational Review, USA, 4(12), 233-243.

DOI: $10.26855 /$ er.2020.12.004
\end{abstract}

Received: November 5, 2020

Accepted: November 30, 2020

Published: December 23, 2020

Corresponding author: Anat Gilat, The School for Advanced Studies, Gordon College of Education, Haifa, Israel.

Email: agilat01@gmail.com

\begin{abstract}
The constitutive statement if knowledge is power? Was an inspiration to the construction of an empirical model to understand if the juxtaposition of social powers (gender and religious regulation) with knowledge (higher education) can be found to yield self- and gender empowerment and was tested among 435 participants: religious and non-religious Jewish and Muslim women. They completed a self-reporting questionnaire (1-5 Likert scale), indicating the existence of a significant empirical SEM model. This confirmed the research hypothesis: gender regulation predicts religiosity, which in turn predicts a stronger perception of higher education as a resource, enhancing self- and gender empowerment. Significant differences were found, by religions, among the groups in the model's variables. This paper could demonstrate how higher education provides a space allowing and challenging empowerment as a dynamic, socio-cultural empirical model.
\end{abstract}

\section{Keywords}

Gender and Religious Regulation, Higher Education as Resource, Self-Empowerment, Gender Empowerment

\section{Introduction}

The article discusses a model according to which higher education can become a springboard for women to gain further knowledge as a power and to empower themselves (Gilat, 2006; Gilat, 2015; Gilat \& Hertz-Lazarowitz, 2008). Positioning education and empowerment together was inspired first by Foucault's (1980, p. 93) thoughts about the relationship between knowledge and power-and between power and knowledge and secondly by Freire's works (1970) highlighting the influence education can have on people by helping them alter their awareness and understanding of their surrounding social reality. These led the current line of inquiry, especially the desire to understand empirically the mechanism by which power and knowledge generate empowerment and how that happens.

In order to empirically examine this, Jewish and Muslim religious and non-religious women students were selected to illustrate issues of "power" and it's centrality in gender and religious regulation. The dichotomous distinction between non-religious or religious, was made in order to simplify on one hand and strengthen on the other, some of the variability and complexity involved in religious labels and identity in Israel. For issues of "knowledge", the university was chosen, as a framework wherein knowledge can be acquired. This choice was strengthened by the rising numbers of women attaining their bachelor's degrees. The United States has seen a rise from 1950, when women represented a minority (23.88\%) of bachelor's degree students, to 2008, when they represent the majority (57.30\%) (Stromquist, 2013a, 
p. 16). Israeli universities have observed a similar rise, from women representing the minority (39.5\%) in 1990, to their constituting the majority (54.5\%) in 2017 (Central Bureau of Statistics, 2018a; Central Bureau of Statistics, 2018b).

To better distinguish issues involving knowledge and power, a choice was made to focus on women who act on their own behalf, acknowledging their values, abilities, and powers. Such women act out of the need to empower themselves through achieving higher education, with all of the emotional, physical and financial investment needed to complete an academic degree; for example: to fight to overcome huge odds, including initial rejection, family disapproval, overwhelming academic and familial tasks or to risk everything in order to deal with success and failure, in order to forge social contacts in a new environment often far from home and familiar environments.

This article can help explain the role of higher education in human development. The literature review examines how issues of the power demonstrated through religious and gender regulation and issues of knowledge shown through the perception of higher education as a resource illuminate its value; the women attribute power to knowledge and convert the knowledge resources they have acquired into self and gender empowerment, through which they can achieve control over their lives.

\subsection{Issues of Power: Gender and Religious Regulation in Israel Today}

Three major religions are represented in Israel: Judaism, Christianity and Islam. At the end of 2018, the distribution of the population by religion was: Jews (74.7\%) Muslims (17.8\%), Christians (2\%) and Druze (5.5\%) (Central Bureau of Statistics, 2019). For women in Israel, belonging to a religious community of one of the three major religions means being subject to ascertain level of gender and religious regulation.

Gender regulation involves the dictation of an individual's behavior by ideologies, social norms, and institutional practices that designate particular behaviors as appropriate or inappropriate in terms of an individual's gender (Zuckerman, 1997); meaning how to live, how to present oneself to others, and how to bring one's needs into harmony with religious beliefs. Social norms refer to the use of religion for one's own ends, such as status, sociability, and self-justification (Cohen, Mazza, Johnson, Enders, Warner, Pasek, \& Cook, 2017).

Both gender regulation and religiosity aim to maintain control, through the family, over women's behavior, in order to increase their commitment to traditional women's roles, such as marriage and birth rate (Alexander, Pinson, \&Yonah, 2010; Yefet, 2016). Therefore, Israeli society is considered to be family oriented. This manifests itself in the division of authority and responsibilities and implies women's dependent position. However, it is possible to detect differences between the attitudes of women belonging to different social groups, based on the form of gender regulation and religiosity common to their communities (Birenbaum-Carmeli, 2009; Fogiel-Bijaoui, 2002; Okun, 2017).

The effect of gender regulation on non-religious women in Israel within the family is less prominent because of the low status of religion and familyism in that group; There the status of the father is equal to that of the mother, and sometimes even lower than hers. The family does not interfere with the life of an individual: every man and every woman is given the freedom to choose their spouse. The marriage age is high, the number of children is low, and the divorce rate is high (Fogiel-Bijaoui, 2002; Lavy \& Zablotsky, 2015; Yefet, 2016). These population groups can be defined as having a weak sense of gender regulation and religiosity and are represented by both Jewish and Muslim non-religious women.

Gender regulation affecting religious women in Israel within the family is more prominent because of the high status of religion and familyism. In religious families, the structure of the family is patriarchal: the father is the dominating authority figure. The family dictates lifestyle choices to the individual and prohibits digressions from the chosen path. In religious families, marriage age is low, the family plays a crucial role in choosing a spouse, the number of children is usually high, and the divorce rate is low (Aksoy \& Billari, 2018; Meler, 2013; Moore, 2004; Schellekens \& Atrash, 2018). Such population groups can be defined as having a strong sense of gender regulation and religiosity. They are represented by both Jewish and Muslim religious women living in Israel.

Despite these gender and religious regulations, many Jewish and Muslim women, even the religious and the orthodox, choose to study at the university level, even if this is inconsistent with their commitment to traditional women's roles. In viewing higher education as a way to empower themselves with knowledge resources, these women take a step toward developing strategies to negotiate the powers that gender and religious regulation imposes on their lives. Women's perception of higher education as a knowledge resource can be seen as their ability both to resist and negotiate with.

Resistance here refers to the development of an internal sense of personal power that enables women to act, whether consciously or unconsciously, against oppressive gender regulation and/or religious norms (Gilat, 2006; Gilat, 2015; Gilat \& Hertz-Lazarowitz, 2008). This personal power acts as a factor that maintains active opposition or resistance and determines its strength (Minson, 1986). The entrance of these women into higher education can be understood as a form of "moral resistance" - the inner forces that emerge when people recognize the influences that oppress and impose in- 
justice upon them, leading them to develop a sense of moral obligation to stand up for themselves and their rights, and to search for solutions. Here this term serves to legitimize women's struggle in coping with gender and religious regulation by employing academic studies as a potential resource to build inner strength (Turiel, 2003, p. 126).

\subsection{Issues of Knowledge: The Perception of Higher Education as a Resource}

Higher education, perceived as a knowledge resource, can be seen both in the number of women turning to higher education at present and in this number's increase over the years (Becher, Hubard, \& Murphy, 2010; Delors, 2013). In 2016/2017, Jewish and Muslim women (both religious and non-religious) constituted 54.5\% and 62\% of all students pursuing a bachelor's degree, respectively, while the percentages of male students pursuing a bachelor's degreewere $45.5 \%$ and 38\%, respectively (Central Bureau of Statistics, 2018a; Central Bureau of Statistics, 2018b). In 2013/2014, 19\% of Israel's ultra-Orthodox religious (Haredi) population reported pursuing, or having pursued, an academic degree - a noticeable increase compared to 2007/2008, when this figure was at $15 \%$. In addition, the percentage of women engaged in academic study (23\%) was significantly higher than that of men (15\%) (Malach, Cahaner, \& Choshen, 2016, p. 12). In 2013, for the first time, the proportion of ultra-Orthodox women working outside the home reached 73\%, compared to 81\% among other Israeli Jewish women (Engelsman et al., 2018, p. 154). This increase can be analyzed as a way for women to identify the potential within higher education in a variety of areas.

The types of potential that women see in higher education as a knowledge resource can be divided into five categories: first is its potential as a professional resource, embodied by the possibility of attaining an academic education and professionalization that ensures economic and social status (Benjamin, 2016; Pellegrino \& Hilton, 2012; Stromquist, 2013a; Maharaj, Blair, \& Chin Yienkee, 2016). Both in the religious and non-religious Jewish and Muslim communities, women's higher education is legitimized as a potential resource for the family's economy (Offer \& Sabah, 2011; Khurshid, 2019).

The second category is the potential of higher education as a source of self-fulfillment, in that it promotes personal and intellectual growth, broadening the learner's horizons. This perception is typical among non-religious Jewish women. It is not common among religious Jewish and Muslim women, since they are expected to find self-realization through religion and their family role (Gilat \& Hertz-Lazarowitz, 2008).

The third category - the potential of higher education as a social knowledge resource, lies in the options the academic campus offers for creating connections and encounters with persons both similar and different from oneself. These options include interpersonal relationships, friendships, rivalries, cultural and political affiliations, and additional possibilities (Deil-Amen, 2011). There is little information available regarding the social interactions of religious Jewish women students who turn to higher education. It is known that religious and especially ultra-Orthodox women turn to religious studies such as the "Beit Yaakov" schools, where they can remain close to their families and communities (Caplan \& Stadler, 2012) which dictate their degrees of freedom for forming social ties (Engelman et al., 2018; Layosh, 2014). Muslim women students who turn to university studies generally distance themselves from their families and from parental supervision; their potential social resources lie in their manifestations of autonomy in decision making, concern for basic needs, independence, and learning new habits and roles (Herzog, 2004; Schellekens \& Atrash, 2018).

The fourth category is the potential of higher education as an affiliation resource, influenced by religious and gender segregation (Ayalon \& Yogev, 2005; Smith, 2011). It seems that the women often chose their field of study based on its potential for affiliation. Jewish women choose first and foremost the two areas of study that are traditionally considered feminine-teaching and nursing; only in third place do they choose the field of business. Muslim women, on the other hand, choose the field of science, which is considered neutral, followed by the field of humanities. Students from both sectors rarely choose the field of technology, which is widely perceived as a traditionally male field (Alon \& Gelbgiser, 2011; Feniger, Mcdossi, \& Ayalon, 2014).

The fifth category is the potential of higher education to serve the woman's community of origin by contributing essential knowledge resources to it (Goldner \& Golan, 2018; Neal, 2014). Religious women choose to specialize in professions that meet the needs of their religious community. Specialization in subjects such as special education, psychology, counseling, etc., addresses the needs of families and children with difficulties (Caplan \& Stadler, 2012; Cohen \& Malach, 2017). Among Muslim women, this community-supporting potential is reflected in their desire to give back to their communities by contributing to areas such as health, education, family, politics, and employment. They aspire to see their community as highly educated and of high value both to themselves and to other communities in Israeli society (Aish \& Gaby-Egozi, 2019; Feniger et al., 2014; Goldner \& Golan, 2018; Khurshid, 2019). Women’s perception of higher education as a resource can be seen as their ability to identify its inherent potential and use it to acquire both self and gender empowerment in order to achieve control over their lives. 


\subsection{Empowerment: Gaining Knowledge Merges into Power}

Empowerment through higher education is ideally seen as a continuous holistic process engaging cognitive, psychological, economic and political dimensions to achieve emancipation. Empowerment in its emancipatory meaning carries wide-ranging implications (Stromquist, 2013b, p. 13) —it brings up the question of personal agency (Gilat, 2015, p. 54; Jones, 2017) rather than reliance on intermediaries, links actions to needs, and results in significant collective change. Therefore, women's perception of higher education as a knowledge resource can be viewed as their ability to identify the potential inherent in it, including the actions they take to mobilize this potential for themselves in the emancipatory sense (Stromquist, 2013b, p. 13) of self-empowerment.

Self-empowerment through higher education can be evaluated using three indicators (Menon, 1999). The first is the level of significance assigned to education, meaning the value or importance attributed by students to their academic studies (Gilat, 2015). The second is the extent of perceived control, meaning the development of a sense of autonomy, expressing an individual's freedom to initiate and direct his or her actions (Garcia-Juan, Escrig-Tena, \& Roca-puig, 2018; Menon, 1999; Spreitzer, 1996). These indicators refer to the degree of control gained in the process of dealing with educational challenges, such as writing demanding papers or theses; the ability to put theories into practice; and developing the skills required for various academic accomplishments.

Third is the extent of perceived competence, defined as a student's ability to succeed in dealing with educational challenges (Delors, 2013; Martin, 2009; Seake, Gibson, Haynes, \& Potter, 2015), such as the ability to read complex theoretical material and perform proficiently in complex exercises. Evaluation of a student's capabilities helps the student understand how to act in different settings: a student with a stronger sense of self-efficacy will set more challenging goals for themselves and have a stronger sense of obligation to achieve them, consequently acquiring greater empowerment (Bandura, 1997; McQuillan, 2005; Stajkovic, Locke, Bandura, \& Lee, 2018).

Among women opting for higher education, the "university effect" appears-that is, the ways in which numerous aspects of a woman's life (such as her sense of self and gender empowerment) are affected by her being educated in academia (Tezer, 2018). Their exposure to many different opinions, varied and expansive knowledge, and ideologies that advocate freedom and emphasize independence accumulate, along with the importance of building equal relationships across genders. Women who have turned to higher education tend to support the equal division of domestic chores and avoid stereotypical concepts regarding gender roles. More and more women belonging to the lower socioeconomic strata consider pursuing higher education and building a career mainly as a result of reflecting on gender inequality, both generally, and in their own families (Gilat, 2006; Gilat, 2015; Khurshid, 2019).

Self and gender empowerment of women through higher education therefore requires the development of a comprehensive range of skills and characteristics in order to achieve various educational goals employing inner strength, such as diligence in the face of difficulties and personal, social, religious or cultural constraints; the ability to ignore distractions that could sabotage the study process; and the determination to maintain control over events influencing academic progress towards the accomplishment of tasks. Thus, the research question was, if it is possible to build an empirical model of acquiring self and gender empowerment through higher education for four groups of female students who live in Israel?

The following six hypotheses were formulated in order to answer this question: (1) a positive correlation can be found between gender regulation and religiosity; and (2) between these variables and the perception of higher education as a resource; as well as (3) between the perception of higher education as a resource and a form of self-empowerment; and (4) between the perception of higher education as a resource and a form of gender empowerment. It was hypothesized that (5) the perception of higher education as a resource serves as a mediator between the independent variables of gender regulation and religiosity and the dependent variables of self-empowerment and gender empowerment. Finally, it was hypothesized that (6) differences can be found between the four groups of female students in terms of the following variables: gender regulation, perception of higher education as a resource, self-empowerment, and gender empowerment.

\section{Methodology}

The Participants were 435 students belonging to four groups: Jewish non-religious women (114), Jewish religious women (112), Arab Muslim non-religious women (109), and Arab Muslim religious women (100); they were between ages 19 and 30. The students were studying for their bachelor's degree (B.A.) at one of four Israeli universities that offer undergraduate and graduate studies in humanities and social science faculties. The participants were chosen using stratified nonrandom sampling from among the Israeli universities fulfilling the above criteria.

The average age of the students was 22.83 years and the range was $19-30$ years ( $\mathrm{SD}=2.13$ years). Most were not mar- 
ried (79.8\%); most married women (with or without children) came from Jewish or Muslim religious backgrounds. Most were third-year students (62.8\%), followed by second-year students (25.5\%), and finally fourth-year students (11.7\%). Most of the students were studying in the faculties of social science (38.4\%) and humanities (33.3\%), some in the faculties of health and welfare (14.9\%), and a few in the faculty of education (13.3\%). During the academic year, most students received financial support from their families to cover tuition fees (53\%) and living costs (48.3\%). Nevertheless, most students (52.4\%) also worked eight hours per week on average (SD=11.38 hours).

The Study Measures consisted of a questionnaire (Gilat, 2006; Gilat \& Hertz-Lazarowitz, 2008). The first part included background information: age, nationality, religion, personal status, economic status and employment, etc. The second part included items measured on a five-point Likert scale, ranging from 1 (highly disagree) to 5 (highly agree): Gender Regulation ( $\alpha=.87$ ) includes five items; for example: "Women's first priority should be to fulfill their roles as mothers and wives"; and "It is best that women be committed to their families first and their career later". The measure of Religiosity was encoded as a dichotomous variable: non-religious or religious. This decision was made in order to simplify some of the variability and complexity involved in religious labels and identity in Israel and was based on a suggestion by Muslim students. The Perception of Higher Education as a Resource $(\alpha=.90)$, included 25 items, for example: "I chose higher education out of the desire to acquire a profession;" and "I chose higher education as a means for self-fulfillment".

The measure of self-Empowerment ( $\alpha=.87$ ) included 16 items; for example: "My studies give me the voice and language required to have influence;" I am able to use the strategies I acquired during my studies to elevate my grade average;" the measure of Gender Empowerment ( $\alpha=.81$ ) included four items; for example: "Higher education gives me the knowledge, tools and power to act on behalf of women;" and "During my studies, I clarified for myself my values and goals as a woman". The questionnaire was printed and given in Hebrew, which is the primary language for reading and writing in academic studies in Israel. The students participated in the study voluntarily. The researcher introduced herself to the students as being interested in the students' personal and academic development during their academic studies.

Data Analysis included the examination of the connections between the variables by structural equation modeling (SEM) using AMOS 15. The differences between the four groups were examined using a two-way multivariate analysis of variance (two-way MANOVA).

\section{Results}

Based on the SEM analysis, the model presented in Figure 1 was constructed. $\beta$-values are presented on the black arrows. $R^{2}$-values are presented in the ellipses above variables names. The compatibility measures of the structural model are given at the bottom of Figure 1.

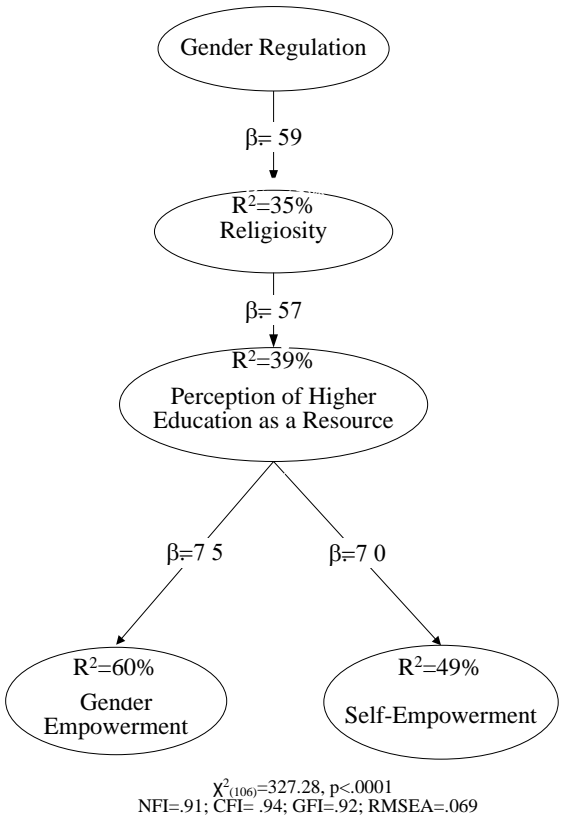

Figure 1. SEM of the Relations Between the Research Variables. 
As can be seen in Figure 1, the normed fit index (NFI) is equal to .91, the comparative fit index (CFI) is equal to .94, and the goodness of fit index (GFI) was .92, which is borderline significant. In combination, these values indicate the model's adequate degree of accuracy. The root means square error of approximation (RAMSA) index, whose value should be less than 0.1, is equal to .069, thus also pointing towards a positive correlation (Edwards, Wirth, Houts, \& Xi, 2012).

All six research hypotheses were confirmed when gender regulation predicted $35 \%$ of the variance in religiosity, that predicted 39\% of the variance in perceiving higher education as a resource. The latter was mediated between gender regulation and self- and gender empowerment. Perceiving higher education as a resource predicts $49 \%$ of the variance in self-empowerment and $60 \%$ of the variance in gender empowerment. The sixth study hypothesis was tested and presented in Table 1 below.

Table 1. Multivariate Analysis of Variance of the Differences Between the Four Groups by Religion

\begin{tabular}{|c|c|c|c|c|c|c|}
\hline \multirow{2}{*}{ Variable } & $\begin{array}{c}\text { Non-Religious } \\
\text { Jews } \\
\mathrm{N}=114\end{array}$ & $\begin{array}{c}\text { Religious } \\
\text { Jews } \\
\mathrm{N}=112\end{array}$ & $\begin{array}{c}\text { Non-Religious } \\
\text { Muslims } \\
\text { N=109 }\end{array}$ & $\begin{array}{c}\text { Religious } \\
\text { Muslims } \\
\mathrm{N}=100\end{array}$ & & \\
\hline & $\begin{array}{c}M \\
(S . D)\end{array}$ & $\begin{array}{c}M \\
(S . D)\end{array}$ & $\begin{array}{c}M \\
(S . D)\end{array}$ & $\begin{array}{c}M \\
(S . D)\end{array}$ & $\boldsymbol{F}_{(1,431)}$ & $\begin{array}{c}\text { Eta } \\
\text { Squared }\end{array}$ \\
\hline Gender Regulation & $\begin{array}{c}2.18 \\
(0.64)\end{array}$ & $\begin{array}{c}3.87 \\
(0.86)\end{array}$ & $\begin{array}{c}3.84 \\
(0.80)\end{array}$ & $\begin{array}{c}4.36 \\
(0.53)\end{array}$ & $190.86 * * *$ & .57 \\
\hline $\begin{array}{c}\text { Perception of Higher Education as a } \\
\text { Resource }\end{array}$ & $\begin{array}{c}3.22 \\
(0.54)\end{array}$ & $\begin{array}{c}3.85 \\
(0.50)\end{array}$ & $\begin{array}{c}3.87 \\
(0.61)\end{array}$ & $\begin{array}{c}3.87 \\
(0.50)\end{array}$ & $47.46^{* * *}$ & .25 \\
\hline Self-Empowerment & $\begin{array}{c}3.63 \\
(0.67)\end{array}$ & $\begin{array}{c}4.01 \\
(0.56)\end{array}$ & $\begin{array}{l}3.63 \\
(0.70)\end{array}$ & $\begin{array}{c}4.10 \\
(0.52)\end{array}$ & $17.55^{* * *}$ & .10 \\
\hline Gender Empowerment & $\begin{array}{c}2.30 \\
(0.85)\end{array}$ & $\begin{array}{c}3.33 \\
(0.82)\end{array}$ & $\begin{array}{c}2.57 \\
(0.97)\end{array}$ & $\begin{array}{c}3.66 \\
(0.70)\end{array}$ & $60.86 * * *$ & .30 \\
\hline
\end{tabular}

$* * * \mathrm{p}<.001$

Significant differences in gender regulation were found between the four groups according to their religiosity. The highest values were obtained for the religious Muslim students and the lowest ones for the Jewish non-religious students. Significant differences in perceiving higher education as a knowledge resource and a tool in self-empowerment were found only between religious and non-religious participants, with the former scoring higher. Significant differences in gender empowerment were found between Jews and Muslims, with Muslims scoring higher, and between religious and non-religious students, with religious students scoring higher. These findings support the empirical model for acquiring self- and gender empowerment through higher education, as well as the existence of significant differences between the four groups of participants.

\section{Discussion}

The discussion section will be presented according to the six hypotheses: The first hypothesis confirmed that the stronger the gender regulation reported by the female students, the stronger their religiosity was. This correlation supports the strong affinity between these two variables, demonstrating that religious supervision over mainstream gender-based behaviors of religious women was defined first and foremost as a mother and wife and fulfilling traditional gender roles (getting married, giving birth to children, and building a family), which are stipulated by the laws of the Jewish Halacha and the Muslim Sharia, both perceived as the core of the holy commandments, and sometimes even sanctioned by state legislation (Alexander et al., 2010; Birenbaum-Carmeli, 2009; Yefet, 2016; Schellekens \& Atrash, 2018). This context provides the background for the next correlation, between religiosity and the perception of higher education as a knowledge resource.

The choice to apply for university studies, even if it goes against the conventions of gender and religiosity regulation can be explain as a subversive action, expressing opposition to methods or patterns of control; such struggles are characterized as local because they represent cases in which people criticize their living conditions, relationships, impact of people or certain groups or institutions on their lives. This concept of power opens a way to understanding its dynamics through the concept of resistance, of which empowerment is one of its manifestations, and the force that sustains, de- 
termines its power and manages it (Foucault, 1982; Minson, 1986).

In the context of resistance, higher education provides a legitimate opportunity for women: on a practical level, it is an opportunity - to leave home for the university; on an ideological level, it is an opportunity to gain access to various resources that reduce commitment to traditional women's roles, increase their commitment to themselves, and help them obtain control over their lives and functions (Gilat, 2006; Gilat \& Hertz-Lazarowitz, 2008; Stromquist, 2013a; Stromquist, 2013b; Tezer, 2018). Acquiring knowledge resources, such as a profession, improves the socioeconomic status of women and their families; attaining knowledge and skills through higher education provides women with social legitimacy (especially in traditionally religious communities) to join the workforce and financially support their families by using the knowledge resources they acquired during their studies (Pellegrino \& Hilton, 2012; Offer \& Sabah, 2011).

This conceptualization also seems to be confirmed by the connection that was found here between the perception of higher education as a resource and between self and gender empowerment. Perceiving higher education as a resource means that the individual envisages the realization of her latent potential through education, for example by utilizing personal abilities; developing a professional career and achieving financial prosperity; making social contacts and establishing friendships; enriching her traditional role with newly acquired knowledge in order to improve her lifestyle; and expanding her potential for social or political promotion within her community of origin. This is a process of empowerment, meaning that the individual is able to take advantage of the realization of latent resources and strengthen personal capabilities to perform academic tasks at the university, such as writing, critical reading and thinking, improving proficiency in communication, verbal expression and the ability to convince others; and initiating actions for one's own sake and for the sake of others (Gilat, 2006; Gilat \& Hertz-Lazarowitz, 2008; Jones, 2017).

The research findings demonstrate that for the participants, self and gender empowerment meant taking advantage of the possibility of gaining access to knowledge, tools and power in order to advance, yet it also necessitated the clarification of the participants' goals and personal values as women. This finding is supported by previous research, describing higher education as an opportunity exposing students to different opinions, extensive and wide-ranging knowledge and ideologies that advocate freedom and stress the need for independence, and the importance of building relationships in which there is gender equality (Benjamin, 2016; Deil-Amen, 2011; Feniger, Mcdossi, \& Ayalon, 2014; Goldner \& Golan, 2018).

To conclude, the perception of higher education as a resource was an important variable in the context of this study. Functioning as a mediator, it acted as a link connecting gender regulation and religiosity to self and gender empowerment-stemming from and also engendering the participants' resistance against gender regulation that is dictated by traditional roles. Empowerment provides the power to enforce this resistance, determining its degree and maintaining its efficacy (Gilat, 2006; Gilat \& Hertz-Lazarowitz, 2008; Maharaj et al., 2016); thus, a woman who sees higher education as a resource will gain the ability to forge her way toward the acquisition of both self- and gender empowerment.

Each variable represented within the empirical model was also tested against religiosity, as is evident from the division of participants into four different groups. The significant differences were found between the four groups in terms of gender regulation with the highest rates among non-religious Muslim women and all religious women (both Jewish and Muslim). The differences were found first to be supported by surveys reporting a subtle increase in the return to religion of the Muslim population occurring in Israel from the 1970s, and which continues to be one of the dominant features of Muslim Arabs living in Israel since then (Khurshid, 2019). Differences between the four groups in terms of gender regulation should be considered in light of other studies that indicate a strong sense of commitment to women's traditional roles among Muslim women living in Israel, manifested by high marriage rates, high birth rates, and low divorce rates (Aksoy \& Billari, 2018; Meler, 2013; Offer \& Sabah, 2011); these characteristics are also typified by Jewish religious women (Caplan \& Stadler, 2012; Moore, 2004).

Significant differences in perceiving higher education as a resource in self-empowerment were found between religious and non-religious participants: higher rates were evident among religious women. The key factor in the process of empowerment among women in general and religious women in particular is their perception of higher education as a knowledge resource, which helps them use their power and practice their abilities and competencies, their commonsense and insight. This helps increase their confidence to express their views concerning their traditional roles, enabling them to attain greater control over their marriage age, more autonomy in their choice of spouse, and control over birth-giving age (Gilat, 2006; Gilat \& Hertz-Lazarowitz, 2008; Fellabaum, 2011; Mihelich \& Storrs, 2003; Stromquist, 2013a; Stromquist, 2013b; Tezer, 2018).

With regard to differences between the groups in terms of self-empowerment, while both Muslim and Jewish participants describe how higher education contributes to their personal empowerment, religious participants (in contrast to their non-religious counterparts) add the realization that higher education contributes to their survival as women in the 
religious community, which denies them an equal position. Their status rises not only within their own family, but also within their communities - even within Jewish and Muslim orthodox religious communities, which are quite determined to exclude women from sources of power (Aish \& Gabay-Egozi, 2019; Khurshid, 2019; Neal, 2014).

The significant differences in gender empowerment found between Jews and Muslims, with higher rates among Muslims, and between non-religious and religious women, and also with higher rates among religious women, can be explained by the fact that non-religious students, by opting for higher education, marked the beginning of their gender empowerment, completing the entire process during their studies. While non-religious students begin to pave their way towards gender empowerment before opting for higher education, religious students only begin this process in the academic world; nevertheless, for both groups, the acquisition of knowledge resources in the context of their academic studies is a way to attain gender empowerment (Abu-Baker \& Azaiza, 2010; Alon \& Gelbgiser, 2011; Benjamin, 2016; Engelsman, Huss, \& Cwikel, 2018).

The theoretical and methodological contribution featured in the article, sheds light on the process of empowerment acquisition through the mediation of knowledge resources, expressing them empirically so they can be generalized as a model for the larger population. Several theoretical claims (Foucault, 1980; Freire, 1970) related to the mechanism through which knowledge resources turn into power and then into empowerment, were supported by this study. An additional contribution lies in the attempt to understand and illuminate the special context of women students from different sectors in Israel, including unique groups such as Orthodox Jews and religious Muslims, whose participation in higher education is neither common nor self-evident, by comprehending how context (gender and religious regulation) influences women's sense of "lack" with regard to resources, and how higher education in turn compensates for this lack, serving as a mediating mechanism generating personal and gender empowerment. All of these contributions help explain the role of knowledge and higher education in developing personal power and empowerment.

\section{Acknowledgements}

This article is based on research supported by the Israel Science Foundation (grant no. 51/05). This article is based on a paper presented at the Annual Meeting of the American Educational Research Association, New York City, March 24-28, 2008.

\section{References}

Abu-Baker, K., \& Azaiza, F. (2010). “Strategies for Closing the Educational Gaps Among Palestinian Couples in Israel.” Journal of Women of the Middle East and the Islamic World, pp. 154-180.

Aish, M., \& Gabay-Egozi, L. (2019). “Intracohort Trends in Ethnic Earnings Gaps: The Role of Education.” Socius: Sociological Research for a Dynamic World, 5: 1-14. doi: 10.1177/2378023119845740 srd.sagepub.com.

Aksoy, O., \& Billari, F. C. (2018). “Political Islam, Marriage, and Fertility: Evidence from A Natural Experiment.” American Journal of Sociology, 123(5): 1296-1340. doi:10.1086/696193.

Alon, S., \& Gelbgiser, D. (2011). “The Female Advantage in College Academic Achievements and Horizontal Sex Segregation.” Social Science Research, 40(1): 107-119.

Alexander, H. A., Pinson, H., \& Yonah, Y. (2010). Citizenship, Education, and Social Conflict: Israeli Political Education in Global Perspective. Jerusalem: Van-Leer Institute \& Routledge.

Ayalon, H., \& Yogev, A. (2005). “Field of Study and Students' Stratification in an Expanded System of Higher Education: The Case of Israel.” European Sociological Review, 21(3): 227-224.

Bandura, A. (1997). Self-efficacy: The Exercise of Control. New York: W. H. Freeman.

Becher, G. S., Hubard, W. H. J., \& Murphy, K. M. (2010). "Explaining the Worldwide Boom in Higher Education of Women.” Journal of Hum Cup, 4(3): 203-241.

Benjamin, O. (2016). “Gendered Corrosion of Occupational Knowledge: Contracting-Out Israeli Social Services.” Equality, Diversity and Inclusion: An International Journal, 35(3): 174-185.

Birenbaum-Carmeli, D. (2009). “The Politics of Natural Family in Israel: State Policy and Kinship Ideologies.” Social Science \& Medicine, 69: 1018-1024.

Blanton, B. S., Broemmel, A. D., \& Rigell, A. (2019). "Speaking Volumes: Professional Development Through Book Studies.” American Educational Research Journal, XX(X): 1-31.

Caplan, K., \& Stadler, N. (2012). From Survival to Consolidation: Changes in Israeli Haredi Society and its Scholarly Study. http://www.vanleer.org.il/en/node/1568 (Hebrew). 
Central Bureau of Statistics. (Students at university by sex, degree, institution and field of study Table 2.4; 2018a). https://www.cbs.gov.il/he/Pages/default.aspx.

Central Bureau of Statistics. (Percentage of women among students, by population group, religion and place of birth, degree and type of institution Table 2.29; 2018b). https://www.cbs.gov.il/he/Pages/default.aspx.

Central Bureau of Statistics (Population by religion table 2.2; 2019). https://www.cbs.gov.il/he/subjects/Pages/\% D7\%90\%D7\%95\%D7\%9B\%D7\%9C\%D7\%95\%D7\%A1\%D7\%99\%D7\%99\%D7\%94-\%D7\%9C\%D7\%A4\%D7\%99-\%D7\%9 3\%D7\%AA-\%D7\%95\%D7\%A7\%D7\%91\%D7\%95\%D7\%A6\%D7\%AA-\%D7\%90\%D7\%95\%D7\%9B\%D7\%9C\%D7\%95\% D7\%A1\%D7\%99\%D7\%99\%D7\%94.aspx.

Cohen, A. B., Mazza, G. L., Johnson, K. J., Enders, C. K., Warner, C. M., H., Pasek, M. H., \& Cook, J. E. (2017). “Theorizing and Measuring Religiosity Across Cultures.” Personality and Social Psychology Bulletin, 43(12): 1724-1736.

Cohen, Y., \& Malach, G. (2017). Ultra-Orthodox Employment: Emerging Rrends. Jerusalem: Democracy Institute.

Delors, J. (2013). “The Treasure Within: Learning to Know, learning to do, learning to live Together and learning to be. What is the Value of that Treasure 15 Years After Its Publication?” International Review of Education, 59(3): 319-330.

Deil-Amen, R. (2011). “Socio-Academic Integrative Moments: Rethinking Academic and Social Integration Among Two-Year College Students in Career-Related Programs.” The Journal of Higher Education, 82, 54-91. doi:10.1080/00221546.2011.11779085.

Edwards, M. C., Wirth, R. J., Houts, C. R., \& Xi, N. (2012). “Categorical Data in the Structural Equation Modeling Framework.” In Handbook of Structural Equation Modeling, edited by R. H. Hoyle, 195-208. New York, NY: Guilford Press.

Engelsman, S. P., Huss, E., \& Cwikel, J. (2018). “How Ultra-Orthodox (Haredi) Israeli Women Cope with Normative and Difficult Pregnancy and Childbirth Experiences.” Nashim: A Journal of Jewish Women's Studies and Gender, 33: 136-157.

Fellabaum, J. (2011). “Conceptualizing Gender Performance in Higher Education: Exploring Regulation of Identity Expression.” NASPA: Journal about Women in Higher Education, 4(2): 127-141. doi:10.2202/1940-7890.1083.

Feniger, Y., Mcdossi, O., \& Ayalon, H. (2014). "Ethno-Religious Differences in Israeli Higher Education: Vertical and Horizontal Dimensions.” European Sociological Review, 31(4), 383-396.

Fogiel-Bijaoui, S. (2002). “Families in Israel: Post Modernity, Feminism and the State.” The Journal of Israeli History, Special Issue: Women's Time, 21(1-2): 38-62.

Foucault, M. (1980). Two Lectures. In “Power/Knowledge”, edited by Gordon, 80-105. Bringhton: Harvester.

Freire, P. (1970). Pedagogy of the Oppressed. New York: Continuum.

García-Juan, B., Escrig-Tena, B. A., \& Roca-Puig, V. (2018). “Psychological Empowerment: Antecedents from Goal Orientation and Consequences in Public Sector Employees.” Review of Public Personnel Administration, 1-30. doi.org/10.1177/0734371X18814590.

Gilat, A. (2006). "Women Experiencing Empowerment Through Higher Education. The Story of Jewish and Arab Women Students, Religious and non-Religious.” PhD doss., University of Haifa, Israel. [Hebrew]

Gilat, A., \& Hertz-Lazarowitz, R. (2008). Jewish and Muslim Religious and Non-Religious Women's Experience of Empowerment: The Model of Acquired Empowerment through Higher Education. Paper presented at the AERA Annual meeting. New York, NY, March 24-28.

Gilat, A. (2015). “The courage to Express Myself: Muslim Women’s Narrative of Self-Empowerment and Personal Development Through University Studies.” International Journal of Educational Development, 45: 54-64.

Goldner, L., \& Golan, D. (2018). "What is Meaningful Civic Engagement for Students? Recollections of Jewish and Palestinian Graduates in Israel.” Studies in Higher Education, 44(11): 1945-1959. https://doi.org/10.1080/03075079.2018.1471673.

Herzog, H. (2004). Both an Arab and a Woman: Gendered, Racialised Experiences of Female Palestinian Citizens of Israel. Social Identities: Journal for the Study of Race, Nation and Culture, 10(1): 53-82.

Jones, R. (2017). “The Student Experience of Undergraduate Students: Towards A Conceptual Framework.” Journal of Further and Higher Education, 42(8): 1040-1054.

Khurshid, A. (2019). “Islamic Traditions of Modernity: Gender, Class, and Islam in a Transnational Women’s Education Project.” Gender \& Society, 29(1): 98-121.

Lavy, V., \& Zablotsky, A. (2015). “Women’s Schooling and Fertility Under Low Female Labor Force Participation: Evidence From Mobility Restrictions in Israel.” Journal of Public Economics, 124(C): 105-121. doi:10.1016/j.jpubeco.2015.02.009.

Layosh, B. (2014). Women of the Threshold: Orthodox Woman Confronting Modern Change. Tel-Aviv: Resling. (Hebrew). 
Malach, G., Cahaner, L., \& Choshen, M. (2016). Statistical Report on Ultra-Orthodox Society in Israel 2016. https:// en.idi.org.il/publications/4282.

Mann, A., \& Di-Prete, T. A. (2013). “Trends in Gender Segregation in the Choice of Science and Engineering Majors.” Social Science Research, 42(6): 1519-1541.

Martin, A. J. (2009). "Motivation and Engagement Across the Academic Life Span: A Developmental Construct Validity Study of Elementary School, High School, and University/College Student.” Educational and Psychological Measurement, 69(5): 794-82.

Maharaj, C., Blair, E., \& Chin Yienkee, S. (2016). “The Motivation to Study: An Analysis of Undergraduate Engineering Students at a Caribbean University.” Journal of Further and Higher Education, 42(1): 24-35.

McQuillan, P. J. (2005). Possibilities and Pitfalls: A Comparative Analysis of Student Empowerment. American Educational Research Journal, 42(4): 639-670.

Meler, T. (2013). “Israeli-Palestinian Women and Their Reasons for Divorce: A Comparative Perspective.” Israel Studies Review: An Interdisciplinary Journal, special volume on Families in Israel, 28(2): 8-41.

Menon, S. T. (1999). “Psychological Empowerment: Definition, Measurement and Validation.” Canadian Journal of Behavioral Science, 31(3): 161-164.

Mihelich, J., \& Storrs, D. (2003). “Higher Education and The Negotiated Process of Hegemony: Embedded Resistance Among Mormon Women.” Gender and Society 17(3): 404-422.

Minson, J. (1986). “Strategies for socialist? Foucault’s conception of power.” In Towards a critique of Foucault, edited by Gane, 106-148. London \& New York: Routledge, Kagan Paul.

Moore, D. (2004). “Gender identities and Social Action: Arab and Jewish Women in Israel.” Journal of Applied Behavioral Science, 40(2): 182-207.

Mullen, A. L. (2014). “Gender, Social Background, and the Choice of College Major in a Liberal Arts Context.” Gender \& Society, 28(2): 289-312.

Mullen, A. L., \& Baker, J. (2015). "Participation Without Parity in US Higher Education: Gender, Fields of Study, and Institutional Selectivity.” NASPA: Journal About Women in Higher Education, 8(2), 172-188.

Neal, J. W. (2014). “Exploring Empowerment in Settings: Mapping Distributions of Network Power.” American Journal of Community Psychology, 53: 394-406.

Offer, S., \& Sabah, M. (2011). “Individual and Familial Determinants of Married Arab Israeli Women’s Labor Force Participation: Trends of Change and Stability.” Marriage and Family Review, 47(5): 326-43.

Okun, B. S. (2017). “Religiosity and Fertility: Jews in Israel.” European Journal of Population, 33(4): 475-507. doi:10.1007/s10680-016-9409-x.

Oplatka, I., \& Tevel, T. (2006). "Liberation and Revitalization: The Choice and Meaning of Higher Education Among Israeli Female Students in Midlife.” Adult Education Quarterly, 57(1): 62-84.

Pellegrino, P. W., \& Hilton, M. (2012). Education for life and work: Developing transferable knowledge and skills in the 21st century. Washington, D.C.: The National Academies Press.

Rappaport, J. (1987). “Terms of Empowerment/Exemplars of Prevention: Toward a Theory of Community psychology.” American Journal of Community Psychology, 15(2): 121-145.

Schellekens, J., \& Atrash, A. (2018). “Religiosity and Marital Fertility among Muslims in Israel.” Demographic Research, 39(34): 911-926. doi:10/4054/DemRes.2018.39.34.

Seake, J., Gibson, S., Haynes, J., \& Potter, A. (2015). "Power and resistance: Reflections on the Rhetoric and Reality of Using Participatory Methods to Promote Student Voice and Engagement in Higher Education.” Journal of Further and Higher Education, 39(4): 534-552.

Shapira, T., Khalid, A., \& Faisal, A. (2010). “Arab Women Principals’ Empowerment and Leadership in Israel.” Journal of Educational Administration, 48(6): 704-15.

Stajkovic, A., Locke, E. A., Bandura, A., \& Lee, D. (2018). “Test of Three Conceptual Models of Influence of The Big Five Personality Traits and Self-Efficacy on Academic Performance: A Meta-Analytic Path-Analysis.” Personality and Individual Differences, 120: 238-245.

Smith, E. (2011). "Women into Science and Engineering? Gendered Participation in Higher Education STEM Subjects.” British Educational Research Journal, 37(6), 993-1014. 
Spreitzer, G. M. (1996). “Social Structural Characteristics of Psychological Empowerment.” Academy of Management Journal, 39: 483-504.

Stromquist, N. S. (2013a). “Education Policies for Gender Equity: Probing into State Responses.” Education Policy Analysis Archives, 21(65): 1-31.

Stromquist, N. S. (2013b). The Theoreticaland Practical Bases for Empowerment. In C. Medel-Anonuevo (Ed.). Women, Education and Empowerment: Pathways towards Autonomy (13-22). Hamburg, Germany: UNESCO Institute for Education 1995.

Tezer, M., \& Aynas, N. (2018). “The Effect of University Education on Lifelong Learning Tendency.” Cypriot Journal of Educational Science, 8(1): 66-80.

Triventi, M. (2013). "Stratification in Higher Education and its Relationship with Social Inequality: A Comparative Study of 11 European Countries.” European Sociological Review, 29: 489-502.

Turiel, E. (2003). “Resistance and Subversion in Everyday Life.” Journal of Moral Education, 32(2): 115-130.

Yefet, K. C. (2016). “Born to Be a Mother: Anatomy, Autonomy, and Substantive Citizenship for Women in Israel.” Harvard Journal of Law \& Gender, 39(1): 257-315.

Zuckerman, P. (1997). “Gender Regulation as a Resource of Religious Schism.” Sociology of Religion, 58: 353-373. 